\title{
The Effect of Net Profit Margin And Return On Asset on Financial Distress of Coal Mining Sector Companies Registered In IDX Period 2014 - 2018
}

\author{
Indah Setyowati $^{\text {a, } 1, *}$, Imam Susanto ${ }^{\text {b,2 }}$ \\ a,b Institut Ilmu Sosial Dan Manajemen Stiami Jakarta \\ ${ }^{1}$ Indahsetyowati123456@gmail.com * ; ${ }^{2}$ imamsusanto07@gmail.com \\ * corresponding author
}

\section{ARTICLE INFO}

Article History

Received, 13-Okt-2020

Reviewed, 23-Okt-2020

Published, 31-Okt-2020

Keywords

Net Profit Margin;

Return On Asset;

Financial Distress;

Coal Mining

\begin{abstract}
This study aims to examine the effect of Net Profit Margin, Return On Asset, on Financial Distress that are calculated using the Altman Zscore. The population in this study is the coal mining companies listed on the Indonesia Stock Exchange period 2014 - 2018. Sampling in this study uses the Purposive Random Sampling method in order to obtain a sample of 30 samples from 6 companies. This research uses a quantitive approach to the type of collaborative research. The data used in the form of company financial statement obtained from the Indonesia Stock Exchange. The data is then analyzed using multiple linier regression methods with SPSS version 26 . The results of the analysis show that partially Net Profit Margin has a negative effect and significant on the Financial Distre. This is evidenced through the $t$ test, where $t$ count is smaller than t table $(-1,738<2,0518)$ and Return On Asset has a positive and significant effect on Financial Distress. This is evidenced through the t test, where $t$ count is bigger than $t$ table and is (4,633 > 2,11991). Simultaneously, Net Profit Margin, Return On Asset has a significant effect on the Financial Distress this is indicated by the significance of the $F$ test value of 0,000 smaller than 0,05 .
\end{abstract}

\section{PENDAHULUAN}

Indonesia memiliki sumber daya alam dan sumber daya manusia yang sama kayanya. Sumber daya alam tersebar diseluruh wilayah Indonesia. Salah satu yaitu pesona tambang Grasberg di Papua sebagai penghasil emas terbesar di dunia. Dengan kekayaan tersebut, seharusnya Indonesia tidak memiliki kesulitan untuk menggarap dan mengolah semua yang dimiliki dalam usaha meningkatkan kualitas hidup nasional. Di antara semua kekayaan alam yang tersedia, kekayaan yang paling menjanjikan untuk dikelola berada di sektor pertambangan. Sektor pertambangan adalah sektor yang akan menyerap begitu banyak tenaga kerja, menggairahkan begitu banyak sektor pendukung dan nilai jual produk yang diambil begitu bernilai. Menurut undang-undang Nomor 4 tahun 2009 tentang Pertambangan Mineral dan Batubara, Pertambangan adalah sebagian atau seluruh tahapan kegiatan dalam rangka penelitian, pengelolaan, dan pengusahaan mineral atau batubara yang meliputi penyelidikan umum, eksplorasi, studi kelayakan, konstruksi, penambangan, pengolahan dan pemurnian, pengangkutan dan penjualan, serta kegiatan pascatambang.

Pertambangan adalah rangkaian kegiatan dalam rangka upaya pencarian, penambangan (penggalian), pengolahan, pemanfaatan dan penjualan bahan galian (mineral, batubara, panas bumi, migas). Sektor pertambangan merupakan 5 bagain dari sektor penyumbang terbesar pertumbuhan ekonomi RI sepanjang tahun 2014 yaitu " sektor pertambangan dengan porsi 9,82 persen, tapi pertumbuhannya rendah hanya 0,55 persen. Kemudian penurunan lifting minyak, batu bara. Tahun lalu pertambangan lebih dari 1 persen yaitu 1,74 persen. Liputan6.com, Jakarta Feb 2015.

Krisis global dewasa ini menjadi ancaman bagi perekonomian dunia. Kondisi tersebut 
membawa implikasi pada memburuknya perekonomian nasional terutama kemampuan dunia usaha dalam mengembangkan usahanya. Perusahaan ialah bentuk badan usaha organisasi bisnis yang memiliki tujuan untuk memperoleh laba dari aktivitas bisnis yang dijalankan. Dalam menjalankan aktivitas bisnis perusahaan tidak selamanya akan berkembang dengan baik sebagaimana yang telah diharapkan dan ada kalanya perusahaan yang dirintis itu akan mengalami kegagalan. Kegagalan perusahaan biasanya dimulai dari kesulitan keuangan atau financial distress.

Perusahaan yang sudah mengetahui adanya tanda-tanda financial distress harus segera mengambil tindakan agar tidak sampai bangkrut atau pailit. Untuk menganalisis kondisi financial distress dalam perusahaan telah banyak penelitian menggunakan rasio-rasio keuangan dan variabel non keuangan seperti kondisi ekonomi, sensitivitas perusahaan terrhadap kondisi ekonomi, opini auditor terhadap laporan keuangan perusahaan, dan perbedaan industri (Almilia dan Kristijadi, 2003). Delisted terutama forced delisted merupakan salah satu indikator bahwa perusahaan sedang mengalami masalah kesulitan keuangan.

Fenomena yang terjadi yaitu dari tahun 2014 sampai tahun 2018 terdapat 17 emiten saham perusahaan di BEI di delisting, paling banyak terjadi pada tahun 20178 saham emitem 2 diantaranya terjadi pada sektor pertambangan yaitu saham BRAU DAN TKGA.

Kebangkrutan merupakan masalah yang harus diwaspadai oleh perusahaan, untuk itu perusahaan harus sedini mungkin mendeteksi kemungkinan kebangkrutan yang akan dihadapinya. Menjadi hal baik apabila perusahaan dapat mengantisipasi dan mencegah adanya kebangkrutan lebih awal sebelum pada saat financial distress.

Financial distress terjadi sebelum kebangkrutan (Yuanita, 2010). Kebangkrutan suatu perusahaan dapat dilihat dari laporan keuangannya dengan cara melakukan analisis dalam bentuk rasio-rasio keuangan. Analisis rasio keuangan adalah perbandingan jumlah dari satu jumlah dengan jumlah yang lainnya kemudian dilihat perbandingannya dengan harapan nantinya akan ditemukan jawaban yang selanjutkan itu dijadikan bahan kajian untuk dianalisis dan diputuskan (Fahmi, 2012:107). Penelitian ini menggunakan metode Altman Z-Score, karena metode ini mampu memprediksi kesulitan keuangan dengan tingkat akurasi yang paling tinggi yaitu 95\% (Harahap, 2015:657).

Menurut Taani dan Banykhaled (2011) rasio keuangan dapat membantu investor dalam membuat keputusan investasi dan dapat memprediksi keadaan perusahaan di masa yang akan datang serta dapat memberikan peringatan awal mengenai penurunan keadaan keuangan perusahaan. Dan melalui rasio keuangan investor dapat melakukan pengawasan untuk memastikan modal yang mereka tanamkan berkembang dengan baik. Secara umum rasio keuangan terdiri dari rasio aktivitas, likuiditas, solvabilitas, profitabilitas, dan pasar. financial distress dapat diprediksi melalui perhitungan rasio profitabilitas seperti net profi margin dan return on asset.

Net Profit Margin atau Margin laba bersih (NPM) merupakan sebuah rasio profitabilitas yang mengukur persentase laba bersih dari suatu perusahaan terkait dengan penjualan bersihnya. Sebuah perusahaan kan dianggap memiliki kulitas yang sangat baik apabila Net Profit Margin nya tinggi atau mendekati nilai penjualan yang mereka targetkan.

Return On Asset adalah salah satu jenis rasio profitabilitas, yang dalam pengukurannya digunakan untuk menilai seberapa baik kinerja perusahaan dalam menghasilkan laba bersih dari pemanfaatan aset yang dimilikinya.

Fenomena lain dari financial distress adalah perusahaan cenderung mengalami kesulitan likuiditas yang ditunjukkan dengan kemampuan perusahaan yang semakin menurun dalam memenuhi kewajibannya kepada kreditur (Hanifah 2013). Platt dan Platt (2002) menyatakan kegunaan prediksi informasi kesulitan keuangan pada perusahaan adalah dapat mempercepat tindakan manajemen untuk mencegah masalah sebelum terjadinya kebangkrutan. Schuppe (2003) menambahkan bahwa pihak manajemen yang tanggap mendeteksi financial distress lebih awal. Kemudian bertindak aktif menganalisa penyebab financial distress dan menerapkan strategi perputaran yang tepat, akan jauh lebih dapat mengendalikan kondisi tersebut. 


\section{KAJIAN PUSTAKA}

Menurut Kasmir (2011:303) laba bersih (Net Profit) merupakan laba yang telah dikurangi biaya-biaya yang merupakan beban perusahaan dalam suatu periode tertentu termasuk pajak.

$$
\text { Net Profit Margin }=\frac{\text { Net Profit }(\text { Before Tax })}{\text { Sales }}
$$

Menurut Kasmir (2014:201), Return On Asset merupakan rasio yang menunjukkan hasil atas jumlah aktiva yang digunakan dalam perusahaan.

$$
\text { Return On Asset }(R O A)=\frac{\text { Earning After Tex }}{\text { Total Assets }}
$$

Menurut Fahmi (2012:158), menjelaskan bahwa definisi dari financial distress adalah : "Plat mendefinisikan financial distress sebagai tahap penurunan kondisi keuangan yang terjadi sebelum terjadinya kebangkrutan ataupun likuidasi."

\section{Cara Memprediksi Financial Distress}

Menurut Syaryadi (2012), Altman's Z- score atau Altman Bankrupty Prediction Model Z-score adalah model yang memberikan rumus untuk menilai kapan perusahaan akan bangkrut. Dengan menggunakan rumus yang diisi (interplasi) dengan rasio keuangan maka akan diketahui angka tertentu yang ada menjadi bahan untuk memprediksi kapan kemungkinan perusahaan akan mengalami kesulitan keuangan atau financial distress.

Rumus untuk menghitung Nilai Z-Score untuk Model Altman's Z-score Fungsi Z (zeta) yaitu:

$\mathrm{Z}=1,2 \mathrm{X} 1+1,4 \mathrm{X} 2+3,3 \mathrm{X} 3+0,6 \mathrm{X} 4+1,0 \times 5$

Keterangan:

$\mathrm{Xl}=$ Modal kerja $/$ Total Aset $(\%)$

$\mathrm{X} 2$ = Laba yang ditahan/Total Aset $(\%)$

$\mathrm{X} 3$ = Laba sebelum bunga dan pajak/Total Aset (\%)

$\mathrm{X} 4$ = Nilai pasar saham biasa da preferen/Nilai buku total utang $(\%)$

$\mathrm{X} 5$ = Penjualan/Total Aset (kali) $\mathrm{Zi}=$ Nilai Z-Score

$\mathrm{Z}$ score Secara umum digunakan :

a) 1,80 or less: Very high Probability of bankruptcy

b) 1,80-2,70: High Probability of Bankruptcy

c) 2,71-2,99: Possible Bankruptcy

d) 3 or above: Far from being Bankruptcy

Berdasarkan Rumusan masalah, Tujuan, penelitian terdahulu, dan kerangka pemikiran maka hipotesis dalam penelitian ini adalah :

H1 : Terdapat pengaruh yang signifikan Net profit margin terhadap financial distress secara parsial di perusahaan pertambangan batubara yang terdaftar di BEI tahun 2014-2018.

$\mathrm{H} 2$ : Terdapat pengaruh yang signifikan Return On Asset terhadap financial distress secara parsial di perusahaan sektor pertambangan batubara yang terdaftar di BEI tahun 2014- 2018.

H3 : Terdapat pengaruh simultan Net profit margin dan Return On Asset terhadap financial distress di perusahaan sektor pertambangan batubara yang terdaftar di BEI tahun 2014- 2018.

\section{METODE PENELITIAN}

Jenis penelitian ini adalah Pendekatan Kuantitatif. Penelitian ini dilakukan pada perusahaan Pertambangan Batubara yang terdaftar di Bursa Efek Indonesia periode 2014- 2018. Populasi 
penelitian sebanyak 15 perusahaan. Kriteria pemilihan sampel dengan cara purposive sampling, dengan criteria sebagai berikut ;

a. Perusahaan Sektor Pertambangan Batubara yang terdaftar di BEI.

b. Memiliki IPO (Initial Public Offering) dan mempublikasikan laporan keuangan yang telah di Audit secara konsisten dan lengkap dari Tahun 2014-2018.

c. Perusahaan mengalami laba bersih negatif sekurang-kurangnya 1 periode laporan keuangan selama periode pengamatan yakni tahun $2014-2018$.

Berdasarkan criteria tersebut diperoleh sampel sebanyak 6 perusahaan selama 5 tahun dengan total 30 data observasi. Metode analisis data dalam penelitian ini menggunakan Analisis Statistik Deskriptif, Uji Asumsi Klasik, dan Uji Hipotesis.

Dengan Kerangka Konseptual Penelitian:

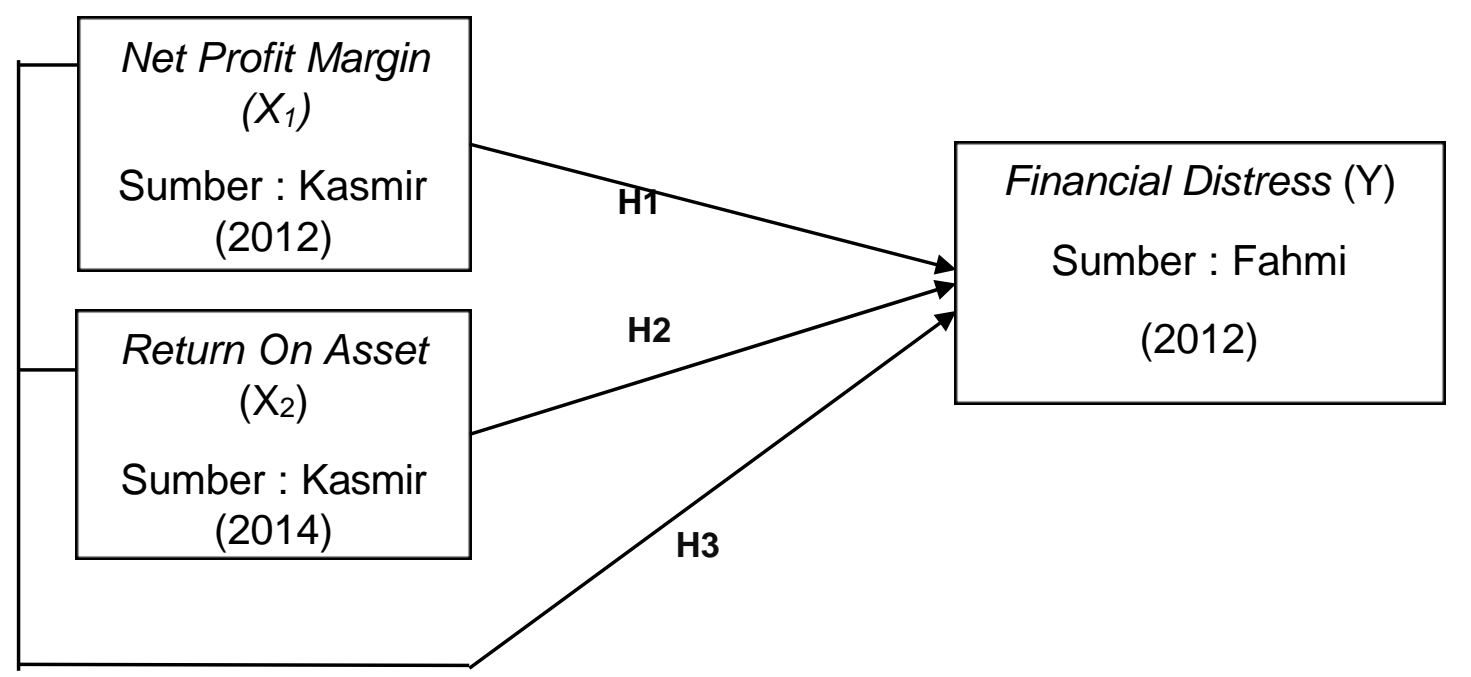

\section{HASIL DAN PEMBAHASAN}

\section{Uji Statistik Deskripti}

Tabel 1. Uji Statistik Deskripti

\begin{tabular}{|l|c|c|c|c|c|c|}
\hline & N & Range & Minimum & Maximum & Mean & Std. Deviati \\
\hline NPM & 30 & 16,94 & $-3,16$ & 13,78 &, 2133 & 2,88804 \\
ROA & 30 & 1,10 &,- 64 &, 46 &,- 0230 &, 18701 \\
& 30 & 17,80 & $-5,09$ & 12,72 & 1,8793 & 3,80695 \\
\hline
\end{tabular}

Sumber : Olah Data, SPSS

\section{Uji Asumsi Klasik}

\section{Uji Normalitas}

Uji normalitas residual dilakukan dengan uji statistic non parametric Kolmogorov-Smirnov (KS). Nilai Kolmogorov-Smirnov Z sebesar 0,094 nilainya diatas $\alpha=0,05$ (Asymp. Sig $=0,094>$ 0,05). Maka dapat disimpulkan bahwa data penelitian berdistribusi secara normal.

\section{Uji Multikolenieritas}

Uji multikolinieritas dilakukan dengan menggunakan variance inflation factor (VIF). Data dikatakan tidak mengalami multikolinieritas apabila nilai VIF $\leq 10$. Hasil pengujian menunjukkan 
seluruh variabel independen memiliki nilai VIF $\leq 10$ sehingga data penelitian ini tidak mengalami multikolinieritas.

\section{Uji Heterokedastisitas}

Nilai signifikansi hitung masing - masing variabel NPM 0,672>0,05 dan ROA 0,904>0,05 lebih dari >0,05 hal ini menunjukkan model diatas bebas heterokedastisitas.

\section{Uji Linieritas}

Nilai Deviation from Linearity sebesar 0,143 lebih besar dari 0,05 maka hubungan antara Return On Asset (X2) dengan Financial Distress (Y) dinyatakan Linier.

\section{Uji Autokorelasi}

Nilai hitung durbin-watson sebesar 2,021 nilai ini kemudian dibandingkan dengan dU tabel sebesar 1,5666 dan dL tabel sebesar 12,837. Adapun syarat dari bebas autokorelasi adalah dimana nilai hitung durbin-watson lebih besar dari dU tabel dan kurang dari $4-\mathrm{dU}$ tabel atau secara matematis dirumuskan $\mathrm{dU}<\mathrm{d}<4-\mathrm{dU}$. Nilai hitung durbin-watson diatas telah memenuhi syarat bebas autokorelasi. Maka dapat disimpulkan model diatas bebas autokorelasi.

\section{Uji Hipotesis}

\begin{tabular}{|c|c|c|c|c|c|c|}
\hline \multirow[b]{3}{*}{ Model } & & \multicolumn{5}{|c|}{ Standardized } \\
\hline & & \multicolumn{2}{|c|}{ Unstandardized Coefficients } & \multicolumn{2}{|l|}{ Coefficients } & \multirow[b]{2}{*}{ Sig. } \\
\hline & & B & Std. Error & Beta & $\mathrm{T}$ & \\
\hline 1 & (Constant) & 2,283 & ,543 & & 4,201 & ,000 \\
\hline & NPM &,- 339 & 195 &,- 257 & $-1,738$ & ,094 \\
\hline & ROA & 13,907 & 3,002 & ,685 & 4,633 &, 000 \\
\hline
\end{tabular}

a. Dependent Variable: ZSCORE

Adapun persamaan regresi pada penelitian kali mengalami kenaikan sebesar ini yaitu sebagai berikut :

$\mathrm{ZSCORE}=\beta \alpha+\beta 1 \mathrm{NPM}+\beta 1 \mathrm{ROA}$

$\mathrm{ZSCORE}=2,283-0,339 \mathrm{NPM}+13,907 \mathrm{ROA}$

Dari persamaan regresi yang dihasilkan maka, diperoleh interprestasi sebagai berikut:

1) Konstanta sebesar 2,283 menyatakan bahwa jika Net Profit Margin, dan Retun On Asset (Variabel bebas) dianggap konstan, maka nilai Financial Distress adalah 2,283.

2) Koefisien regresi Net Profit Margin sebesar -0,339 menyatakan bahwa jika setiap kenaikan Net Profit Margin sebesar satu nilai, sementara variabel lainnya bernilai tetap. Maka, Financial Distress akan mengalami penurunan sebesar 0,339.

3) Koefisien regresi Return On Asset sebesar 13,907 menyatakan bahwa jika setiap kenaikan Return On Asset sebesar satu nilai, sementara variabel lainnya bernilai tetap. Maka, Financial Distress akan mengalami kenaikan sebesar

$13,907$.

\section{KESIMPULAN}

Hasil penelitian menunjukkan bahwa Net Profit Margin berpengaruh negatif dan tidak signifikan terhadap Financial Distress. Pengaruh tersebut ditunjukkan dengan nilai dari thitung = 1,738 sedangkan ttabel pada signifikan 0,05 yaitu sebesar 2,0518. Maka nilai thitung lebih kecil dari ttabel, dalam hal ini berarti variabel Net Profit Margin (X1) berpengaruh negatif tetapi tidak signifikan terhadap Financial Distress (Y) pada perusahaan sektor pertambangan batubara yang terdaftar di Bursa Efek Indonesia pada tahun 2014 - 2018. Dengan koefisien regresi bernilai negatif 
(-) sebesar -0,339, dalam persamaan regresi ZSCORE = 2,283 - 0,339 NPM - 13,907 ROA.

Hasil penelitian menunjukkan bahwa Return On Asset memiliki pengaruh positif yang signifikan terhadap Financial Distress. Pengaruh tersebut ditunjukkan dengan nilai dari thitung = 4,633 sedangkan ttabel pada signifikan 0,05 yaitu sebesar 2,0518. Maka nilai thitung lebih besar dari ttabel, dalam hal ini berarti variabel Return On Asset (X2) memiliki pengaruh positif dan signifikan terhadap Financial (Y) pada perusahaan sektor pertambangan batubara yang terdaftar di Bursa Efek Indonesia pada tahun 2014 - 2018. Hal ini sejalan dengan penelitian yang dilakukan oleh Barlianta Uno, dkk (2014) yang mengkaji salah satu variabel yaitu Return On Asset terhadap Financial Distress dengan signifikansi 0,043 < 0,05 menunjukkan bahwa Return On Asset berpengaruh positif dan signifikan terhadap Financial Distress. Semakin tinggi ROA maka akan semakin besar juga tingkat return/payback yang diterima oleh perusahaan. ROA sangat berguna bagi manajemen perusahaan dalam melakukan pengelolaan aktivitas operasi dalam perusahaan.

Hasil penelitian menunjukkan bahwa Net Profit Margin dan Return On Asset berpengaruh signifikan terhadap Financial Distres. Pengaruh tersebut dapat dilihat dari hasil Uji F bahwa Fhitung 10,911 dan nilai Ftabel sebesar 3,35 dengan signifikan 0,000 kurang dari 0,05. Sehingga dapat disimpulkan bahwa nilai Fhitung lebih besar dari Ftabel sehingga dapat ditarik kesimpulan bahwa H0 ditolak H1 diterima. Yang berarti antara Net Profit Margin (X1), dan Return Aset (X2) secara simultan berpengaruh signifikan terhadap Financial Distress (Y) pada perusahaan sektor pertambangan batubara yang terdaftar di Bursa Efek Indonesia tahun 20134- 2018.

Selain itu, berdasarkan uji koefisien korelasi sebesar 0,679 yang artinya variabel bebas Net Profit Margin, dan Return On Asset mempunyai hubungan dengan variabel terikat yaitu Financial Distress sebesar 0,669. Sedangkan berdasarkan uji koefisien determinasi (R Square) diperoleh nilai sebesar 0,449 atau 44,9\% yang artinya secara bersama-sama Net Profit Margin,dan Return On Asset dapat menjelaskan variasi dari variabel terikat yaitu Financial Distress sebesar 0,449 atau 44,9\% dan untuk sisanya 55,1\% dipengaruhi oleh variabel lain yang tidak diteliti oleh peneliti.

Hasil penelitian ini mendukung hasil penelitian yang dilakukan oleh Mohd. Ripais (2014) yang mengkaji Pengaruh Rasio Likuiditas, Rasio Leverage, Rasio Profitabilitas Terhadap Kondisi Financial Distress Perusahaan Manufaktur yang Terdaftar di BEI . Menunjukkan bahwa NPM dan ROA secara bersama-sama berpengaruh terhadap Financial Distress.

Dari beberapa penelitian terdahulu yang peneliti gunakan sebagai perbandingan dan acuan dalam penelitian ini, didapatkan bahwa Financial Distress tidak hanya dipengaruhi oleh rasio keuangan berupa Net Profit Margin dan Return On Asset. Tetapi, ada beberapa jenis rasio keuangan lain seperti: Return On Equity, Current Ratio, Quick Ratio, Total Asset Turn Over, Net Sales, Inventory Turn over, dan Debt to Equity Ratio juga dapat mempengaruhi kondisi Financial Distress sebagai variabel terikat. Sehingga dapat disimpulkan bahwa rata - rata nilai kontribusi pada variabel bebas dalam penelitian kali ini yaitu sebesar $19 \%$.

\section{DAFTAR PUSTAKA}

Affuah, Allan. 2004. Business Model: A Strategic Management Approach. McGraw Hill: New York

Agnes Sawir. 2005. Analisis Kinerja Keuangan dan Perencanaan Keuangan. Jakarta: PT Gramedia Pustaka Utama

Alexandri, Moh Benny, 2008. Manajemen Keuangan Bisnis, Alfabeta, Bandung.

AI Haryono Jusuf. 2001. Dasar-dasar Akuntansi Jilid 2. Yogyakarta: STIE YKPN

Brigham, Eugene F \& Daves, Philip R. 2003. Intermediate Financial Management. USA: Thompson South Western.

Damodaran, A. 2001. Corporate Finance anf Theory Practic, John Wiley \& Son, Inc. Hal 114-487.

Darsono dan Ashari. 2005. Pedoman Praktis Memahami Laporan Keuangan. Yogyakarta: CV. Andi Offset. 
Fahmi, Irham. 2012. “Analisis Kinerja Keuangan”, Bandung: Alfabeta.

Ghozali, Imam. 2016. Aplikasi Analisis Multivariete Dengan Program IBM SPSS 23 (Edisi 8). Cetakan ke VIII. Semarang : Badan Penerbit Universitas Diponegoro.

Hanafi, Mamduh M. dan Abdul Halim, 2014, Analisis Laporan Keuangan., Edisi tujuh., UPP AMP YKPN, Yogyakarta.

Hanifah, O. 2013. Pengaruh Struktur Coporate Governance dan Financial Indicators Terhadap Kondisi Financial Distress. Jurnal Maksi Undip: 25-53.

Hans Kartikahadi, Rosita Uli Sinaga, Merliyana Syamsul, Sylvia Veronika Siregar (2016). Akuntansi Keuangan Berdasarkan SAK berbasis IFRS. Jakarta: Salemba

Harahap, Sofyan Syafri. 2015. Analisis Kritis atas Laporan Keuangan. Edisi 1-10. Jakarta: Rajawali Pers.

Ikatan Akuntansi Indonesia. 2009. Standar Akutansi Manajemen, PSAK No.1 : Penyajian Laporan Keuangan. Jakarta: Salemba Empat.

Ikatan Akutansi Indonesia. PSAK No. 2 Tentang Laporan Arus Kas - edisi revisi 2015. Penerbit Dewan Standar Akuntansi Keuangan: PT. Raja Grafindo

Jumingan. 2006. Analisis Laporan Keuangan. Jakarta: PT. Bumi Aksara.

Kasmir. 2008. Bank dan Lembaga Keuangan Lainya. Edisi Revisi 2008. Jakarta: PT. Rajagrafindo Persada.

Kasmir. 2010. Pengantar Manajemen Keuangan. Jakarta: Kencana Prenada Media Group.

Kasmir, 2011, Analisis Laporan Keuangan, Edisi 1, Cetakan 4, Penerbit PT Raja Grafindo Persada, Jakarta.

Kasmir. 2012, Analisis Laporan Keuangan. Jakarta: PT. Raja Grafindo Persada.

Kasmir, 2014. Analisis Laporan Keuangan, Edisi Pertama, Cetakan Ketujuh. Jakarta: Raja Grafindo Persada.

Kasmir. 2008. Analisis Laporan Keuangan. Jakarta: Raja Grafindo Persada.

Kasmir. 2010. Pengantar Manajemen Keuangan. Jakarta: Prenada Media Group.

Kasmir. 2008. Bank dan Lembaga Keuangna Lainya. Edisi Revisi 2008. Jakarta: PT. Rajagravindo Persada.

Kasmir.2011.Bank dan Lembaga Keuangan lainnya. Edisi Revisi 11. Rajawali Pers. Jakarta.

Kasmir. 2013. Analisis Laporan Keuangan. Rajawali Pers: Jakarta

Kasmir \& Jakfar. 2012. Studi Kelayakan Bisnis. Cetakan ke Delapan. Jakarta: Kencana.

Kieso dan Weygandt. 2011. Intermediate Accounting edisi tahun 2011. Jakarta: Peraturan Pemerintah Nomor 71 Tahun 2010 tentang Standar Akuntansi.

Munawir, S. 2012. Analisis Informasi Keuangan, Liberty, Yogyakarta

Peraturan Pemerintah Nomor 71 Tahun 2010 tentang Standar Akuntansi Pemerintahan.

Plat, H., dan M. Plat. 2002. Prediction Corporate Financial Distress: Refleksions on Choice Based Sample Bias. " Journal of Economics and Finance 26(2): 184-197.

Prastowo Dwi, Juliaty Rifka. 2002. Analisis Laporan Keuangan-Konsep dan Aplikasi. Cetakan Kedua. AMP YKPN. Yogyakarta.

Rudianto. 2012. Pengantar Akuntansi Konsep \& Teknik Penyusunan Laporan Keuangan, Penerbit: Erlangga, Jakarta.

Soemarso. 2010. Akuntansi Suatu Pengantar. Edisi 5. Cetakan Keenam. Jakarta: Rineka Cipta. 
Srimindarti. 2006. Balanced Scorecard Sebagai Alternatif untuk Mengukur Kinerja. Semarang: STIE Stikubank.

Sugiyono. 2016. Memahami Penelitian Kualitatif. Bandung : Alfabeta.

Sundjaja, Ridwan S. Barlian, Inge. 2003. Manajemen Keuangan. Edisi Keempat, Literata Lintas Media, Klaten.

Sutrisno, Edi. 2009. Manajemen Sumber Daya Manusia Edisi pertama. Jakarta: Kencana Prenada Media Group.

Syaryadi, Fikri. 2012. Pengaruh likuiditas Terhadap Financial Distress Perusahaan Industri Textile dan Garmen yang Terdaftar di Bursa Efek Indonesia. Digilib. Polsri.ac.id.

Taani dan Banykhaled. 2011. "The Effect of Financial Ratio, Firm Size, and Cash Flow From Operating Activities on Earning per Share". International Jurnal of Social Sciences ang Humanity Studies, Vol.3, No. 1. Pp 197-205.

Walter T., et al. 2012. Akuntansi Keuangan IFRS Edisi Kedelapan Jilid 1. Jakarta: Erlangga.

Warren dkk. 2005. Pengantar Akuntansi. Jakarta: Salemba Empat.

Yuanita. (2010). Persepsi Mahasiswa Akuntansi Mengenai Faktor-faktor yang Membedakan Pemilihan Karir. Skripsi. Universitas Diponegoro, Semarang. 